\title{
A Conference Built on Trust
}

\author{
Deborah Hafner DeW inter
}

\section{Abstract}

In A pril 2001, 265 participants from twenty countries including representatives of the governments, intergovernmental organizations, non-governmental organizations, UNHCR, and former refugees met in N orrköping, Sweden, for the International Conference on the Reception and Integration of Resettled Refugees. Fundamentally, the success of the conference resulted from the overarching operating principles in the planning process which affirmed that all resettlement countries, traditional or emerging, had something positive and unique to contribute, and that no hierarchy would influence the equal value of comments made. As a result, a spirit of cooperation and trust was built that characterised the spirit of the conference and continues to influence the post-conference phase of the Integration Initiative.

\section{Résumé}

Au mois d'avril 2001, 265 participants provenant de 20 pays, y compris des représentants de gouvernements, d'organismes inter-gouvernementaux, d'organisations non-gouvernementales, du HCR ainsi que d'anciens réfugiés, se sont réunis à N orrköping, en Suède, à l'occasion de la Conférence internationale sur la réception et l'intégration de réfugiés réinstallés ( «International Conference on the Re ception and Integration of Resettled Refugees »). Le succès de la conférence est dû principalement au fait que les principes directeurs qui ont présidé à toute l'étape de préparation ont réaffirmé que tous les pays accueillant les réfugiés, que ce soient les pays-hôtes traditionnels ou ceux qui sont en passe de le devenir, avaient une contribution unique et positive à faire, et qu'aucune hiérarchie n'influencerait la valeur égale des commentaires faites. Par conséquent, cela à créé un climat de coopération et de confiance qui a caractérisé toute la conférence et qui continue à influencer la phase post-conférence de l'I nitiative d'intégration.
Somehow the distinctions between the respective roles of Government, NGO, UNHCR and former refugees- which sometimescause lines to be drawn in the sand- were less noticeable in this process, because... a level of trust had been established early on.1

\section{Introduction}

helnternational Conferenceon the Reception and Integration of Resettled Refugees (ICRIRR), a key event within a broader Integration Initiative supported by the United Nations High Commissioner for Refugees' partners in resettlement, was held at Vildmarkshotellet in Norrköping, Sweden, on April 25-27, 2001. Two hundred and sixty-five participants from the eighteen resettlement countries as well as two ad hoc resettlement countries (Great Britain and Germany) attended ICRIRR, which was hosted by the Swedish $N$ ational Integration Office. These participants represented the major donor countries and major supporters of refugee protection. Among the participants were representatives of the governments, intergovernmental organizations, nongovernmental organizations, and UNHCR field, re gional, and headquarters staff, as well as former refugees. All eight of the emerging resettlement countries were also represented at ICRIRR. This was the first time that both the traditional and emerging resettlement countries were able to meet in an international forum to exchange best practices in the reception and integration of resettled refugees. $^{2}$

It also seems to have been thefirst timein institutional memory that most of thestandard operating procedures for organizing an international event of this scope were abandoned in favour of a more participatory and democratic approach to conference planning. There was, for example, no secretariat appointed to ensure that the objectivesset by themajor stakeholdersin thisinitiativewould be carried out.

Instead, a consultant with expertise in integration issues and conference organizing was identified and empowered to work collaboratively with states, NGOs, 
UNHCR staff, and former refugees in designing a strategic approach that would ultimately lead to closer working relationships and the exchange of "best practices" between the tripartite partners involved in the resettlement of refugees. ${ }^{3}$ The consultant was given a desk, a tel ephone, a computer, and a warm welcome upon arrival at UNHCR Headquarters in $M$ arch of 2000 . She was also welcomed unconditionally into the heart of the Resettlement Section and treated with all the respect ordinarily afforded resettlement officers. Within three days of the consultant's arrival in Geneva, she was accompanied by the Chief of the Resettlement Section, Department of International Protection, UNHCR, and a senior resettlement officer to Sweden for the purpose of meeting her counterparts at the Swedish National Integration Office in Norrköping. Together, the consultant and her Swedish colleagues would be responsiblefor ensuring that a first-class international conference would be organized in twelve months' time.

The immediate rapport established between the consultant and her Swedish colleagues at the $\mathrm{N}$ ational Integration $\mathrm{O}_{\text {ffice }}{ }^{4}$ was very helpful in the design and implementation of the conference. While it was soon recognized that the working "chemistry" between these key colleagues was indeed positive, moresignificantly, they found that they shared a mutual vision for inclusiveness and a democratic process in theidentification and selection of Steering Group members from the diverse constituencies of the international resettlement communities. But all the "chemistry" and shared vision in the world would not have resulted in a successful endeavour had not therespective supervisors and, indeed, institutions themselves fully supported and empowered these colleagues throughout the implementation of their planning responsibilities. Furthermore, without the dedicated commitment, creativity, and practical assistance of the core group of colleagues that comprised the Executive Committee of the ICRIRR Steering Group, neither the focal points at UNHCR nor the Swedish $\mathrm{N}$ ational Integration Office alone could have provided the leadership necessary to ensure success in the planning of the conference. $^{5}$

In the end, the favourable outcome in the planning and implementation of the International Conference on the Reception and Integration of Resettled Refugees was dependent upon the willingness of all concerned within the Steering Group, Executive Committee, and individual conference sessions to work collaboratively across cyberspace with colleagues they had never met, who resettled refugees using significantly different policies, philosophies, and systems, spoke different languages, and lived in other timezones. Fundamentally, the success of the ICRIRR initiative resulted from the overarching operating principles in the planning process which affirmed that, whether new or well seasoned, all resettlement countries had something positive and unique to con- tribute, and that no hierarchy or protocol would influence the equal value of comments made by members of the Steering Group - whether representing the governments, intergovernmental organizations, non-governmental organizations, UNHCR field, regional, or headquarters staff, or former refugees themselves.

That is why, when 265 representatives from twenty countries (most of whom had never met prior) walked in to the Vildmarkshotellet conference centre outside Norrköping, Sweden, on April 25, 2000, they greeted each other like old friends, commenting on how they had never "felt a spirit quite like this between participants at a conference, before."

\section{Background}

1999 Annual Tripartite Consultations on Resettlement Serve as I mpetus for ICRIRR

The impetus for the International Conference on the Reception and Integration of Resettled Refugees stemmed from discussions that took place during the 1999 Annual Tripartite Consultations on Resettlement (ATC) hosted by UNHCR in Geneva. While it was affirmed that refugees were resettled to ensuretheir protection and provide them with a durable solution, and that the criteria for resettlement were governed by well-defined and commonly endorsed guidelines outlined in the Resettlement $\mathrm{H}$ andbook, it was also noted that no significant focussed effort had ever been made by the international community to discuss and evaluate the various models of reception and integration in the resettlement countries.

Increasing Diversity of Resettlement Countries and Refugee Groups P oses Challenges

This evaluation was deemed particularly important given the fact that the number of resettlement countries had increased from ten to eighteen, and that $\mathrm{UNHCR}$ refugee referrals were increasingly more diverse, including nationalities with which the general public in resettlement countrieswerenotfamiliar. Thegovernments, non-governmental organizations, and other implementing partners were therefore facing unique challenges in actively leading, informing, and assisting local communities to facilitate effective resettlement. Given the addition of eight new resettlement countries, UNHCR was also receiving requests for international assistance from them in the implementation of their emerging reception and integration programs. All of these developments and issues of concern pointed to the necessity for the international resettlement community to collectively examine these issues and challenges. 
Need for Comparison of "Best Practices" in Reception and Integration

The delegates attending the 1999 Annual Tripartite Consultations therefore agreed that steps should be taken to facilitate the planning of an international conference designed to exchange ideas and endorse recommendations relating to the reception and integration of resettled refugees. It was further agreed that the ultimate goal of the conference would be to promote a lively and continuing exchange of ideas and experiences on how best to facilitate effective integration- both for those resettled refugees identified as being particularly at risk, and those who might not be in need of immediate protection but had compelling reasons to be removed from their countries of refuge, having no other options available to them except resettlement.

\section{Effective Integration and Its Role in Sustaining Support for Resettlement Policy}

The tripartite partners in resettlement affirmed that because resettlement is used for two critical purposes-as a tool of international protection and as a durable solution for those who have no other hope of a normal life- the resettlement countries should beas effective as possiblein supporting, guiding, and strengthening the integration process for resettled refugees. It was also noted that the relative "success" in facilitating effective integration had bearing upon the degree to which receiving communities continued to endorse and support national resettlement policies. While acknowledging that there had been a number of recent European Union (EU) initiatives with regard to the integration of spontaneously arriving refugees, it was felt that the focus of this conference should beupon the reception and integration of resettled refugees.

\section{Tripartite Partners and Former Refugees Plan and} Implement Conference

As the "success" of integration was thought largely to rely upon the degree to which the governments, NGOs, and UNHCR were able to forge effective partnerships, it was envisioned that both the conference planning process and conference participation should include representatives from the public authorities and NGOs responsible for implementing national policy, as well as UN HCR and resettled refugeesthemselves (including those who would be considered particularly at risk).

Sweden H osts, with Strong Support from the N ordic Countries, US, and Canada

The generous offer of the Swedish National Integration Office to host the conference, together with the commitment of funding primarily from the Nordic countries, with assistance also provided by the United States, Canada's Department of Citizenship and Immigration $(\mathrm{CIC})$, the German Marshall Fund
USA, and the Ford Foundation, enabled UNHCR to identify and deploy a reception and integration specialist to serve as facilitator for the International Conference on the Reception and Integration of Resettled Refugees as well as for the broader integration initiative into which the conference was designed to fit as a midpoint catalyst.

\section{Strategic Planning Process}

Identification of Steering Group, Executive Committee, and W orking Chair

Part of the strategy in the design of the conference planning process was to identify and recruit specialists in the resettlement countries to serve on a Steering Group. These were drawn from the state and local governments, intergovernmental organizations, NGOs, and grassroots refugee and community-based organizations engaged in policy development and reception and integration programs. Given the number of participants involved in the Steering Group, an Executive Committee of the Steering Group was also formed to pilot the planning process and take responsibility for the results. With broad direction from the Steering Group, the Executive Committee was responsible for guiding the shaping of the agenda, monitoring the assignment of tasks, approving presenters identified by the Steering Group, and ensuring that clear and timely communication was provided to all Steering Group members throughout the planning process. A Working Chair from the Swedish National Integration Office, Erik Stenström, was appointed by the Executive Committee to work closely with the UN HCR Facilitator to maximizeaccountability and transparency as well asto foster collegial relationships between the representatives of the eighteen resettlement countries in all phases of the planning process. In addition, the Department of Citizenship and Immigration of the Government of Canada, represented by M s. Lynda Parker, Senior Advisor in the Resettlement Division of the Refugee Branch, played a key leadership role on the ICRIRR Executive Committee. Canada's contributions also included the assignment of a gifted young policy analyst, M s. Tracey Spack, who took thelead in facilitating the editorial process for the framework papers generated by experts involved in the overall planning process.

\section{Development of $\mathrm{M}$ andate Document and M ission} Statement

Following the July 2, 2000, Steering Group M eeting, a document entitled " $M$ andate and Principles, Roles and Responsibilities for the Implementing Structures in the Planning of the International Conference on the Reception and Integration of Resettled Refugees" ${ }^{6}$ was drafted 
to provide guidance in the development of the conference. The conference objectives, which had been outlined in the $M$ andate document, were subsequently incorporated into the M ission Statement. Featured prominently on the ICRIRR Agenda following the November 17, 2000, Steering Group meeting, the $M$ ission Statement of the conference was to provide an international forum for theexchange of ideas and means of supporting refugee resettlement among the traditional and emerging resettlement countries. Planned as the midpoint catalyst in an ongoing process of exchanging "best practices" in the integration of resettled refugees among the resettlement countries, goals for the conference included: drafting commonly endorsed principlesfor the "successful" reception and integration of resettled refugees that are applicable regardless of the level of funding available to resource resettlement programs; facilitating both formal and informal links and exchanges between the various resettlement countries; gathering resources for the development of a reception and integration handbook; and strengthening the reception and integration programs of traditional and emerging resettlement countries.

Refugee Leadership Brings I ntegrity to the Planning Process M embers of the Steering Group and ExecutiveCommitteewere committed to identifying and supporting the participation of former refugees on both the Steering Group and Executive Committee of ICRIRR. Special funding from the German M arshall Fund USA was obtained for the support of NGO and refugee participation in the planning process, augmented by support provided by the governments. Canada, the United States, and Sweden respectively identified and supported the involvement of three former refugees on the Executive Committee of the ICRIRR Steering Group. Their perspectives provided a "reality check" during the planning process and helped to motivate the involvement of some fifty former refugees in the implementation of the conference. The Ford Foundation also helped facilitate the participation of two former refugees at the conference itself.

\section{Strategy behind Steering Group Process}

Inherent in the strategy behind the Steering Group process was the goal of establishing a comfortable working rapport between representatives of the eighteen resettlement countries in order to initiate an immediate exchange of information, country to country and constituency to constituency. It was also designed to break down the myriad tasks in the planning of the conference so that each of the countries involved would share equitably in the work, to foster a sense of "ownership" of the final product, and ultimately to build towards the goal of drafting commonly endorsed principles for the "successful" reception and integration of resettled refugees. This process engaged local resettlement constituencies in an analysis of their respective "best practices" and in building bridges for the development of new partnerships among the resettlement constituencies of the eighteen resettlement countries and the sharing of "best practices" on an international level.

\section{Design of the ICRIRR Agenda}

Through a series of threemajor Steering Group meetings (M ay 4, 2000; July 2, 2000; and November 17, 2000) and five Executive Committee meetings (July 2, 2000; November 16 and 18, 2000; January 14, 2001; February 23, 2001; and A pril 23 and 28, 2001) over thecourse of eleven months, an agenda was crafted, taking into consideration the three major themes identified by the Steering Group in the design of successful resettlement programs. These themes were: Preparing Refugees and Receiving Communities; Common N eeds of Resettled Refugees; and Special N eeds of Resettled Refugees.

In addition to the seventeen individual breakout sessions identified under these three major themes, three more topics requiring special emphasis were identified by the Steering Group for incorporation into the agenda as discussion groups. Thesetopicswere: Building Capacity with Refugee Involvement for the Reception and Integration of Resettled Refugees; Placement Strategies to Enhance Effective Integration of Resettled Refugees; and Effective Orientation as a Critical Component in the Integration of Resettled Refugees.

\section{Conceptual Framework for Evening Activities}

As part of the strategic planning process for the conference agenda, two special evening events were planned. The first, hosted by the Director General, M r. Andreas Carlgren, and the staff of the Swedish National Integration Office, was conceptually designed to demonstrate what it means to be "Swedish." As one member of the Steering Group who works closely with refugees in Sweden had phrased it during a planning discussion, "Refugees are often told by Swedish nationals: 'You need to be more Swedish!' But what does it mean to be 'Swedish?'" The first evening's dinner and musical productions were planned to share the "essence or soul of Sweden," as Working Chair Erik Stenström summarized it.

The second evening, hosted by UNHCR's Regional Representative for the Baltic and Nordic Countries, M r. Gary T roeller, and hisstaff, featured a dinner and fiftieth anniversary event commemorating the 1951 Convention Relating to the Status of Refugees. To complete the evening, a musical group consisting of former refugees from a number of different cultural backgrounds gave a performance around the theme of how refugees sustain 
their spirits as they are received and integrated into resettlement countries.

\section{Designation of Lead Countries for the Development of Conference Sessions}

Following the Steering Group's identification of broad themes and individual topics for the provisional ICRIRR agenda, a special Steering Group meeting was convened in Washington, D.C., on N ovember 17, 2000, to seek commitment from each resettlement country to accept responsibility for leading individual tracks, discussion groups, or breakout sessions on the agenda. In the subsequent Executive Committee meeting held on November 18,2000, the offers of commitment to lead conference tracks, discussion groups, and individual breakout sessions were considered and final decisions made. Lead countries wereadvised that it was their responsibility to engagethose countries indicating a strong interest in a particular topic to assist in the development of the related session. A revised provisional agenda was circulated which listed both lead countries and countries indicating a strong interest in assisting with the development of every session on theagenda. A country focal point was designated to ease communication between those countries involved in international planning coalitions, and local steering groups in the resettlement countries began meeting regularly in order to coordinate the selection of facilitators, rapporteurs, and presenters for their respective sessions.

Development of Resettlement Country Program D escriptions It had been recommended, in the first Steering Group meeting held on M ay 4, 2000, that each resettlement country should develop a Resettlement Country Program Description to provide a foundational understanding of the various models and methods represented among the eighteen countries of resettlement. The Canadian Government, Citizenship and Immigration Branch, took the lead in drafting a comparative grid of the key elements in each country's reception and integration program, following up this project with the drafting of a Global Overview paper. These tools enabled individual conference session leaders to identify those resettlement countries with special strengthsor representativemodels that would behelpful to include in specific panel presentations. Furthermore, these documents provided practitioners and resettlement policy makers in each of the resettlement countries the opportunity to become more knowledgeable about the models and methods for the reception and integration of resettled refugees implemented in other countries

\section{Development of Framework Papers and Session Summary Forms}

The Executive Committee of the Steering Group also requested that a brief framework/discussion paper be written for each session on the agenda. The three-part structure for the papers was designed to provide an overview of topics, description of key issues emerging, and questionsto focus the discussions at the conference. In addition, lead countries were asked to complete a standard session summary form indicating who would be serving as facilitator, rapporteur, presenter(s) or panellists as well as providing a brief summary of the content and approach to the session. All papers and session summary forms were completed prior to the start of the conference and posted on the Swedish National Integration Office's website with links to the UNHCR website, as well as distributed in a hard-copy binder format to each conference participant as part of the ICRIRR registration process. No single resettlement country's programs or models of reception and integration were to be spotlighted in framework papers or sessions. Rather, lead countries were asked to do their utmost to provide a broadly representative view of the topic and engage colleagues from other resettlement countries in the drafting process of the papers as well as in the planning process for the sessions.

\section{Emerging Resettlement Countries: Current Status and Future Challenges}

As part of the planning process, an analysis was made of the current status and future challenges of the resettlement programs of the emerging resettlement countries. Subsequent requests by the governments and implementing partners of the emerging resettlement countries to identify and send suitable experts in reception and integration were met and deployees dispatched to Benin, Burkina Faso, Argentina, Brazil, and Chile. In the course of this process, special links were forged, for example, between the Southern South American resettlement countries and Spain, and between Canada and Benin and Burkina Faso, so that resources and experience gained might be shared between countries with similar language backgrounds.

Special care was taken to plan a pre-ICRIRR meeting for emerging resettlement countries to provide an overview of the conference agenda and link them with their counterparts among the traditional resettlement countries. In addition, simultaneoustranslation was provided in Spanish and French for all plenary sessions and Track 2 breakout sessions on the Common N eeds of Resettled Refugees. Volunteer interpreters accompanied other participants to sessions where simultaneous translation was not available. Provisional and final agendas, both "At A Glance" and "Annotated" versions, were translated into Spanish and French, thanks to collaborative efforts by Canada, Spain, Argentina, Brazil, and Chile. 


\section{Pre-Conference M eetings and Workshops}

Study Visits

The option of participation in study visits to reception and integration programs and projects was structured into the planning process in conjunction with Steering Group and Executive Committee meetings (e.g., in M adrid, Spain; in N ew York City; Sioux Falls, South Dakota; and the greater W ashington, D.C., area in the U nited States; and in Dublin, Ireland), as well as in conjunction with the conferenceitself. Thestudy visit component of the planning process as a whole provided a meaningful opportunity to receive first-hand orientation to the models and methods of implementing reception and integration programs for those who chose to take advantage of these opportunities. Thevisitsalso served to initiate the development of some informal links and exchanges between expertsfrom the different resettlement countries, a goal of the broader integration initiative.

Expanded Executive Committee M eeting (A pril 23, 2001, in Stockholm)

An expanded ICRIRR Executive Committee meeting was held in Stockholm, Sweden, on M onday, April 23, in order to provide a thorough briefing for members and other key participants on the revised conference agenda, logistics, and both the Facilitator and Rapporteurs' Workshop and the Emerging Resettlement Countries Workshop to be held the afternoon and evening of A pril 24, 2001, respectively. M s. Lynda Parker of the Canadian Government, $\mathrm{CIC}$, gave an overview of the Summary Session and Conference Conclusions so that key leaders at the conference would have a clearer understanding of how the commonly endorsed Principles would be formulated. It was decided that a special rapporteur's debriefing meeting would beheld after each day's sessions to synthesize principles emerging from the sessions and to adjust any aspects of conference logistics that might be necessary for the smoother implementation of the sessions. M r. Erik Stenström provided an overview of how the resourceroom and multimedia centre would work, as well as the registration process.

Facilitator and Rapporteurs' Workshop (A pril 24, 2001, in Norrköping)

From the beginning of the planning process, it was understood that the success of the conference would largely depend upon the skills and talents of the session facilitators and rapporteurs. Hence, a special training session was scheduled before the start of the conference, co-facilitated by the W orking Chair, M r. Erik Stenström, and the ICRIRR Facilitator, Ms. Deborah D eW inter, with assistance by M s. Eva N orström, President of the Swedish Refugee Council, and M r. Sean H enderson, Projects $M$ anager, Refugee Services, $N$ ew Zeal and I mmigration Service.
Emerging Resettlement Countries Workshop (A pril 24, 2001, in N orrköping)

H osted by M r. Ruben Ahlvin of the Swedish Migration Board, theW orkshop and Dinner for Emerging Resettlement Countries was co-facilitated by M s. Susan Krehbiel, Reception and Integration Specialist, deployed by UNHCR to the southern South American resettlement countries of Argentina, Brazil, and Chile, and M s. M aria Vega of the UNHCR Regional Office in Madrid, Spain.

\section{ICRIRR Participation and Proceedings}

Goals for Broad-Based Representation M et

The initial goal of the Steering Group and Executive Committee to limit participation to 250 representatives from the eighteen resettlement countries and six ad hoc resettlement countries was exceeded by fifteen persons, for a total of 265 conference registrants from twenty countries. ${ }^{7}$ The goal of inclusivity was achieved as countries supported theattendance of municipal and national governmental representatives, local and national NGO representatives, former refugees, and others representing, for example, grassroots service providers, employers of refugees, and media specialists.

\section{Participation by Former Refugees}

Some fifty former refugee participants resettled in the eighteen countries of resettlement served as panellists, presenters, speakers, session leaders, facilitators, and rapporteurs during the conference. Their voices provided other partners with a "reality check" on "best practices" shared, and principles drafted, and their leadership and contributions infused both the planning process and implementation of sessions with greater integrity.

\section{Structure of Conference Agenda}

As noted in the "Background" section of this proceedings report, theagenda featured threeprimary tracks reflective of the three major themes of the conference, each organized by co-chairing countries. Following the simultaneously scheduled plenary sessionsfor theindividual tracks, a series of topical breakout sessions were offered, each led by one of the resettlement countries, with assistance provided by other countries indicating a "strong interest" in that topic. Three additional topics were structured as simultaneously held Discussion Groups: $A, B$, and $C$. The separate structuring of these discussion groups simply allowed for wider exposure to these topics by conference participants. Detailed information on the approach, speakers, facilitators, rapporteurs, and key issues presented and discussed during the course of each of these breakout sessions and discussion groups may be found in 
their respective Session Summary Forms ${ }^{8}$ and Executive Summaries of the respective Rapporteur Reports.

\section{Commonly Endorsed Principles ICRIRR Principles}

The Conclusions and Recommendations session of the Conference, moderated by Dr. Elizabeth Ferris of the World Council of Churches and M r. Goran Rosenberg, the Chair of the Conference, successfully resulted in the common endorsement of fifteen general principles to guide the promotion of "successful" integration of resettled refugees by all eighteen resettlement countries. ${ }^{9}$ The spirit of mutual affirmation of these guiding principles by the governments, intergovernmental organizations, and non-governmental organizations of the traditional and emerging resettlement countries, as well as former refugees and UNHCR representatives from both the field and headquarters, spoke well of the planning process leading up to the conference. Special credit must, however, be attributed to Dr. Elizabeth Ferris, who collaborated with members of the ICRIRR Executive Committee, facilitators, and rapporteurs to identify and shape these principles. The Preamble to the ICRIRR Principles document, drafted by Dr. Ferris, leads off with a significant quote by one of the refugee panellists who spokeat the Opening Plenary of the conference: "You can't feel grounded until you belong. You can't belong until you're accepted." Quoted in full below, the Preamble goes on to provide a meaningful perspective and helpful context in framing the fifteen Principles resulting from the proceedings of the International Conference on the Reception and Integration of Resettled Refugees:

Refugees strengthen societies through their cultural diversity and the contributions which they bring. Weaffirm that resettlement of refugees works. M ost refugees integratesuccessfully into their host communities and most of the support and services provided by governments, refugee communities, non-governmental organisations and the public makes a difference.

Resettlement is an important tool of refugee protection and a durablesolution for many refugees. It is not a substitutefor asylum, but rather a complementary way of providing protection to people in need. Resettlement offers refugees the possibility to begin new lives and to become fully participating members of society. Given global needs and the success of resettlement as a durable solution, we believethat the use of resettlement should be expanded in thefuture.

The challenge for states and for UNHCR is to ensure that resettlement selection is carried out in a fair, transparent, and equitable manner based on refugee needs for protection and for durable solutions. A particular challengefor states is to beinclusivein their resettlement criteria and not automatically to exclude groups or countries from consideration. While we acknowledge that resettlement may not be appropriate in every situation, it should be seen as an integral component of a comprehensive international response.

Experience with resettlement varies from country to country. Some countries have long resettlement histories while others are new to the process. But all resettlement countries are committed to facilitating refugee integration, to nurturing a hospitableenvironment for refugees, and arewilling to learn from one another. While integration occurs within a framework of national policy and in a particular cultural context, it is fundamentally a personal process through which refugees develop a sense of belonging, make friendships, and enjoy mutual respect in their new society.

Following the Preamble, the fifteen Principles were organized under four sub-headings in order, first, to attempt to define what the process of integration is about; second, to emphasize the fact that refugees themselves are central to the success of the integration process; third, to emphasize that building capacity for the nurturing of hospitable receiving communities is absolutely fundamental in maximizing the potential for successful integration; and fourth, to emphasize that the strengthening of partnerships in each segment of the refugee resettlement community is al so essential for success in the integration process.

The fifteen Principles endorsed at ICRIRR, quoted in their entirety, follow:

Integration

1. Integration is a mutual, dynamic, multi-faceted and on-going process. "From a refugee perspective, integration requires a preparedness to adapt to the lifestyle of the host society without having to lose one's own cultural identity. From the point of view of the host society, it requires a willingness for communities to be welcoming and responsive to refugees and for public institutions to meet the needs of a diverse population." [Adapted from the European Council on Refugees and Exiles, "Policy on Integration," 1999.]

2. Integration is "multi-dimensional in that it relates both to the conditions for and actual participation in all aspects of the economic, social, cultural, civil and political life of the country of resettlement as well as to refugees' own perceptions of, acceptance by and membership in the host society." [Adapted from the European Council on Refugees and Exiles, "Policy on Integration," 1999.] 
3. Opportunities for resettled refugees to become citizens and to enjoy full and equal participation in society represent an over-arching commitment by governments to refugee integration.

4. Family reunification is crucial to refugee integration. Similarly, relatives and ethnic community networks can play key roles in successful refugee integration.

5. A multi-dimensional, comprehensiveand cohesiveapproach that involves families, communities and other systems can help refugees to restorehopeand to re build their lives.

\section{Refugees at the Centre}

6. Refugees bring resources and skills to the countries in which they resettle. Host societies are strengthened and enriched by the contributions of refugees.

7. Refugee participation and leadership are essential in the development, implementation and evaluation of both refugees' own individual settlement and integration programs.

8. Underlying the practical, tangible needs which refugees have are more fundamental needs for dignity, security, social connectedness, and identity. Both these more fundamental needs and immediate material needs must be addressed.

9. Enabling refugees to use their own resources and skills to help each other is a priority.

10. Responding to the range of needs specific to the refugee experience will improve resettlement programs and enhance integration.

Strengthening Receiving Communities

11. Building community capacity for equitable partnership in refugeereception and integration involvesall sectors of the community.

12. Refugees integrate themselves. The responsibility of the public, private and community sectors is to work alongside refugees as facilitators to create an environment in which people can be empowered.

13. The public should receive accurate and timely information about refugee situations. Receiving communities require additional specific information in preparing for the arrival of refugees in their communities. In both cases, the media have an important role to play.

Strengthening Partnerships

14. Multi-faceted partnerships need to becontinually developed and strengthened among governments, refugees, communities, non-governmental organizations, and volunteers.

15. Strengthening relationships between those working to identify refugees in need of resettlement and the commu- nities wherethey will be resettled isimportant to the resettlement process.

Concluding Remarks by Representatives of the

Emerging Resettlement Countries

It was particularly meaningful to receive very positive assessments of the conference from the perspectives of representativesfrom theemerging resettlement countries and to see how the planning process had assisted these countries in gaining the confidenceto move forward with theimplementation of their programs. A Chilean government representative, for example, noted that the conference had been very helpful to their group of participants in that they realized the challenges faced with their first group of refugees was similar to challenges commonly faced by the traditional resettlement countries. "I'm going back to Chile with thousands of ideas to share with government officials. W hilewe can't implement them all at once, we can put them on the tablefor later consideration," she said.

As a newly emerging resettlement country, Brazil found that participation in the conference assisted the authorities responsiblefor the implementation of resettlement to gain the confidence and tools necessary to move the process forward more expeditiously. Dr. Nara M oreira da Silva, General Coordinator of the National Refugee Committee of Brazil's M inistry of Justice, not only felt more confident, but also expressed pride in Brazil's motivation for offering resettlement as a tool of protection and durable solution for refugees. As she stated in her concluding remarks:

I leave the conference feel ing very proud of Brazil's decision to provide resettlement. While in other countries it is clear that refugee resettlement is seen as an economic benefit, in Brazil we are clear that refugee resettlement is a humanitarian commitment that we can make. In spite of our own economic difficulties, and other problems we may face as a country, we have to do what we can to help those in need.

M eanwhile, in the written evaluation of a grassroots re settlement worker from New Zealand who participated in a panel presentation at ICRIRR, appreciation was expressed for the "open and warm communicative style" in which the conference was conducted. In expressing her thanks for the diversity and inclusiveness of the participants in the design of the conference, shenoted on behalf of the grassroots workers present that "... we felt we were part of [ICRIRR] before we came." 


\section{Conference Conclusions}

$M$ eeting Goals and Expectations

Both the formal and informal evaluations of the International Conference on the Reception and Integration of Resettled Refugees were consistently positive. Some examples of the common themes that emerged from both verbal and written comments were that there seemed to bea "special spirit" at the conference - a phrase that was repeatedly used to describe the mutually supportive dynamic that participants experienced throughout the conference. Furthermore, distinctions between government, intergovernmental, NGO, UNHCR, and former refugee participants were not very obvious, nor did the more formal protocols observed in other settings between senior and junior ranking participants seem to characterize the interactions at ICRIRR. By way of illustration, at one juncture, and unbeknownst to the individual making the request, a Director General was asked to provide informal translation for a representative from one of the emerging resettlement countries during a topical breakout session. Without hesitation, the Director General proceeded to providea whispered interpretation of the presentations made by the panellists and thereafter endeavoured to be as present and helpful as possible to the colleague needing interpretation. Similarly, representatives of the emerging resettlement countries noted that al though they had arrived in Sweden feeling some apprehension about their status as newcomers to the world-wide resettlement community, they very quickly felt that their opinions and insights were valued on an equal basis with representatives of the more traditional resettlement countries. Participants were extraordinarily impressed by the generosity and quality of the welcome they received from their Swedish hosts, in respect to both the contributions and commitment by M r. Andreas Carlgren and his colleagues at the Swedish National Integration Office and those who hosted the study visits in Sweden, and to the professionalism and hospitality of the staff of Vildmarkshotellet. Special mention was repeatedly made of thewonderful evening event and the musical groups that provided a glance into the "soul" of the Swedish people.

Although the planning processes were complex and timeconsuming, requiring patience with different time zones, philosophies, and cultures, participants repeatedly commented that thejoint planning strategy enabled them to devel op positive relationships with their colleagues from other countries prior to the start of the conference, enabling a more creative and informal exchange of information and insights at the conference. Again, although the collaborative strategy for developing the framework papers for each conference plenary and breakout session, and the requirement that these papers be finalized before the start of the conference seemed initially to be a daunting task, the results were appreciated, not only for the value of theresources produced, but also because of the relationships established throughout the process. Participants were surprised and pleased that in less than an hours' plenary discussion, eighteen resettlement countries represented by participants from diverse sectors could mutually agree upon and endorse fifteen significant Principles to guide the "successful" reception and integration of resettled refugees.

\section{Specific Accomplishments}

There was clear consensus among participants that goals for both the planning process and the conference itself had been satisfactorily met. Some of the specific accomplishments achieved were the establishment of strong bonds between the policy makers and reception and integration practitioners of the eighteen current resettlement countries; also, individuals involved in the implementation became acquainted with one another and each other's programs, policies, and respective strengths and challenges. Also, resources were shared, and views and philosophies exchanged. Participants learned where questions could be answered or needs for expertise met. Furthermore, an impressive set of documents that didn't exist before was produced, providing resources that put the challenges inherent in the reception and integration process in clear focus and pointed to some models and methods that have worked for colleagues around the world. These included an annotated bibliography on integration issues for resettled refugees; eighteen Resettlement Country Program Descriptions; a fifty-page document entitled Brief $\mathrm{H}$ istory of Resettlement, providing a comparative grid of the programs of the eighteen current resettlement countries; a Global O verview paper which offers a comprehensiveand informative perspective on the resettlement models in operation worldwide; twenty-five framework papers on specific topics identified through the Steering Group discussions as representing key issues challenging the countries of resettlement, papers designed to serve as the backbone of the Integration $\mathrm{H}$ andbook Project; a set of twenty-five executivesummaries listing every "best practice" mentioned in each of the individual sessions represented on the ICRIRR Agenda for the mutual strengthening of reception and integration programs; and a collection of over one hundred definitions by refugees of what integration has meant to them, courtesy of the Government of Canada, $\mathrm{CIC}$.

\section{Summary}

Participants from the governments and from the intergovernmental and non-governmental organisations, as well as UNHCR staff and former refugees attending the 
International Conference on the Reception and Integration of Resettled Refugees affirmed that the ICRIRR planning process worked. The commitment of funding from the N ordic countries, the United States, Canada, the German M arshall Fund USA, and the Ford Foundation, in combination with the dedicated efforts of the host country, Sweden, and facilitation provided by the UNHCR's Resettlement Section of the Department of International Protection, made it possible for a truly collaborative and democratic process to be designed and implemented. The enthusiastic and responsible participation of Steering Group and Executive Committeemembersensured that the respective tasks assigned to each country involved in the planning process were completed in a timely and effective manner. And perhaps most significantly, each step of theprocess was designed to meet real needs expressed by the respective constituencies of the eighteen countries of resettlement.

The relationships forged and the levels of trust established early in theplanning process culminated in therareexperience of the International Conferencefor the Reception and Integration of Resettled Refugees in Norköpping, Sweden, that 265 participants from twenty different countries will not soon forget.

\section{Notes}

1. This statement is from the closing remarks of Ms. Debbie Elizondo, Chief, Resettlement Section, D epartment of International Protection, UNHCR, at the International Conference on the Reception and Integration of Resettled Refugees.

2. The eight emerging resettlement countries are: Argentina, Benin, Brazil, Burkina Faso, Chile, I celand, I reland, and Spain. The ten traditional resettlement countries include: Australia, Canada, Denmark, Finland, The Netherlands, New Zealand, Norway, Sweden, Switzerland, and the U nited States.

3. Deborah Hafner DeW inter, UN HCR's consultant in the organization of the International Conference on the Reception and Integration of Resettled Refugees, is theformer AssociateDirector for Program and Administration of thenational offices of Church W orld Service Immigration and Refugee Program in New York, NY (1996-99) and al so served as the Program Director for Resettlement at Lutheran Immigration and Refugee Service in $\mathrm{New}$ York, 1991-96. M s DeW inter, an ordained pastor who has lived and worked for twenty-three years in Taiwan and Hong Kong, has significant experience in the reception and integration of refugees overseas as well as domestically in the United States. She received her undergraduate degreefrom Luther College in Decorah, lowa, in 1973 and earned a M aster of Divinity degree from Yale Divinity School, N ew H aven, Connecticut, in 1985.

4. TheSwedish $\mathrm{N}$ ational Integration Officeteam wasled by M r. Erik Stenstrom, Legal Counsellor, who also served as the Working Chair of the ICRIRR Executive Committee), together with M r. Goran Kostesic, Planning M anager (and former refugee), and M s. Ingela Dahlin, Project M anager. Fully supported by the Director General, M r. AndreasCarlgren, M r. Stenstrom took every oppor- tunity to apply a democratic and participatory approach to leadership in the planning of the conference. Mr. Stenstrom's twelve years of experience working in immigration and integration issues within both the M inistry of Foreign Affairs and Interior M inistry, together with the expertise acquired through participation in a number of Parliamentary Committees in the field of citizenship, served as apt preparation for his leadership role in the planning of ICRIRR.

5. M embers of the Executive Committee of theICRIRR Steering Group included: Thomas Albrecht, UNHCR; M arzia Ali, CCR, Canada; Henrik Ankerstherne, Denmark; $M$ artha Arroyo, CEAR, Spain; Fariborz Birjandian, CCIS, Canada; Deborah DeWinter, UNHCR; Debbie Elizondo, UNHCR; Sean Henderson, New Zealand; Mark H etfield, RCUSA; Goran Kostesic, Sweden; Nicoline Miller, Denmark; Eva N orstrom, SRC, Sweden; Lynda Parker, Canada; M argaret Piper, RCOA, Australia; Areti Sianni, ECRE; Erik Stenstrom, Sweden (W orking Chair); M arieSullivan, N ew Zealand; Ka Ying Yang, SEARAC, USA. M s. Tracey Spack, Canada $(\mathrm{CIC})$, also provided extensive support to the members of the Executive Committee and was responsible for preparing an extensivecomparativestudy of therespective programs in the eighteen countries of resettlement.

6. The $M$ andate document may be found on the Conference website at: http://www.integrationsverket.se/internatconf/ intconf.html or by links found at www.unhcr.ch on the "Resettlement" web page, under the subtopic "Integration Initiative."

7. In addition to the eighteen resettlement countries, the United Kingdom and Germany (two of six ad hoc resettlement countries) were represented at ICRIRR.

8. Available for reference on the ICRIRR website.

9. These Executive Summaries will eventually be posted on the conference website.

Deborah H afner DeWinter is a consultant, Resettlement Section, Department of International Protection, U nited $\mathrm{N}$ ations $\mathrm{H}$ igh Commissioner for Refugees. 